\title{
Creative Development of Young School Children Within Multicultural Environment
}

\author{
Dormidontova L.P. \\ I.N. Ulyanov State Pedagogical University \\ Ulyanovsk, Russia \\ d1963lp@mail.ru
}

\author{
Zabbarova M.G. \\ I.N. Ulyanov State Pedagogical University \\ Ulyanovsk, Russia \\ mari-na-z@yandex.ru
}

\author{
Chernova T.V. \\ Grammar school №79 \\ Ulyanovsk, Russia \\ Tatyana_chernova55@mail.ru
}

\begin{abstract}
The article focuses on research and methodological aspects of young schoolchildren creative development within multicultural environment of the primary school. In the article the scientific and methodical aspects of creative development of junior schoolchildren in the multicultural educational process in primary school were carried out. A comparative analysis of the junior students creative development problem at the present stage of the psychological-pedagogical science development was carried out. The concept of creativity, selected methodological approaches and principles of the pedagogical process organization in the primary school and special pedagogic conditions were refined. The educational program on familiarizing children with musical folk culture is modeled, criteria, indicators of younger pupils creative development in the multicultural educational environment by means of musical folklore are developed. The problem is analyzed on the modern stage of psychology and pedagogics development. The pedagogical experience of the Russian, Tatar, Mordovian and Chuvash people regional cultures involving is arranged and summarized.
\end{abstract}

Keywords-creative development; creative abilities; multicultural environment; national traditions; pedagogical conditions component.

\section{INTRODUCTION}

The strategy of modern education involves offering every student an opportunity to show their talents and achieve creative potential which implies the implementation of personal plans. In the context of pedagogics, the question of present interest is the creative development of young schoolchildren. A prominent place in fulfilling the task is devoted to the traditions of peoples living in the Volga region. Nowadays the child lives within a multicultural region and constantly communicates with the bearers of different cultural traditions. Therefore the importance of appealing to the customs and traditions of different people on a social and pedagogical level is determined by multiculturalism of most regions and social demand of the state to develop creative individuals. They bring about the opportunity for pedagogical search for the innovative teaching and educational methods. On the scientific-theoretical level the relevance of the research is based on the theoretical insufficiency of using national traditions problem in the contents of education and an inadequate rationale for the pedagogical conditions of young schoolchildren creative development within multicultural environment of the primary school.

According to Leonid Lurye, the multicultural environment necessary for the comprehensive development of an individual must contain two tendencies, such as developing awareness of the national culture, as well as seeking to join the global civilization together with this culture [13, p. 173].

\section{LITERATURE REVIEW}

We understand multicultural environment as a part certain educational institution educational environment which represents a complex of conditions affecting development of a personality ready to effective interethnic communication while preserving original ethnical identity and seeking to understand other cultures, respect their cultural community and be able to live in peace and harmony alongside other members of different nationalities. [18, p. 17]

Following T.V. Poshtareva, R.A. Kutbiddinova distinguishes the basic functions of a multicultural educational environment:

- cultural awareness (resulting in discovering the national culture of an individual, as well as other peoples' cultures);

- value-oriented function (developing of the personal values and relations system within the process of intercultural communication);

- ethnocultural self-preservation (offers an opportunity to preserve and protect their own identity, understand ethnocultural and ethnopsychological peculiarities);

social integration (allows to educate a citizen who cares about preserving the integrity of the country and is able to adapt to the living within the conditions of the modern multicultural society); 
- creative function (allows an individual to achieve their creative potential through the development of cognitive and social activity) (134) [10, p. 175].

Comparative analysis of scientific studies demonstrates complexity of the developing creativity problem. Its theoretical foundation is based on philosophical questions (M.M. Bakhtin, N.A. Berdyaev, E.V. Ilyenkov) [1, 2, 8, 9], psychological questions (D.B. Bogoyavlenskaya, L.S. Vygotskiy, V.N.Druzhinin, A.N. Leontyev) [3, 4, 5, 11], pedagogical questions (O.V. Dybina, K.V. Tarasova) [7,14]. A prominent place in the process of analyzing creative development of children is devoted to the studies of the creative work emotional regulation special aspects (A.N. Luk and others) [10], creative motivation (A. Maslow, G. Allport and others) $[11,12]$, general aptitudes, creative activity, level of skills and knowledge (S.L. Rubinstein, B.M. Teplov et al.)[20, 21,22].

Despite the abundance of theoretical developments, modern science faces many difficulties in identifying the essence of creativity, the concept of the individual creative development. The educational aspect of the primary school children creative development associated with the conditions of their development, software, choice of diagnostic tools, forms of organization of the educational process is insufficiently studied. Analysis of scientific literature and practice of education in primary school revealed a number of contradictions: those between the existing social demand for the individuals capable of finding creative solutions to a variety of problems and insufficient scientific and theoretical development of the children creative development in multicultural educational environment, including the identification of educational conditions for its implementation; and those between the great educational potential of folk traditions and the lack of their use in practical work with children.

In the research, creative work is defined as an activity (process and result), resulting in the creation of something new, as an integral personal quality characterized by the level of knowledge and ideas, ways of action, the level of perception, imagination, the desire to change, to be active and independent. Creative work is manifested and realized in its own intense activity and assumes that the individual possesses the ability to create (creativity) and the ability to create something new (creative abilities involve the creative level of the development of the abilities). Creativity is considered as a general ability to creative work and is characterized by the speed and accuracy of mental operations, logical thinking skills, originality of verbal associations, creative thinking and imagination. Creative abilities are defined as individual psychological characteristics of a person that are formed, developed and manifested in the process of creative activity. Creativity is associated with motivation (interests and preferences), temperament (emotional sensitivity) and mental abilities. They are characterized by emotional intensity of creative activity, positive motivation for creative work, knowledge and skills required for this type of activity. Creative works of children are always full of bright emotions. The unity of affect and intelligence acts as a unity of emotional and creative development of children. Identifying the emotional sphere as dominant in children, L. S. Vygotsky and B. M. Teplov note that the constructive means of creativity activation is art, which is character- ized by sense-feeling and imaginative perception [4, 21]. Motivational features of the creative personality are the desire for the process of creativity, self-expression, and sustained enthusiasm for the content of creative activity. Positive motivation is based on positive incentives. The emotional intensity of the process of children's creativity leads to an increased development of new motives for activities. That fact essentially rebuilds the emotional and motivational sphere of the child and facilitates creative development.

Based on the results of the research conducted by O.V. Dybina, K. V. Tarasova and G.M.Tsypina, the structural components of young schoolchildren creative development within multicultural environment by means of folk music were determined: cognitive, emotional and motivational (sustainable internal need for creative activity, a combination of emotional and creative motivation), and creative action-related components (independent performance of creative tasks) [6, 19].

\section{RESEARCH METHODOLOGY}

Theoretical analysis of academic literature allowed to justify the model of children creative development within a multicultural educational environment. It uses the structure of the pedagogical process established in the national pedagogical science: targeted, organizational and pedagogical, substational and activity-oriented, evaluative and effective components.

The following approaches are distinguished as methodological approaches and principles to ensure the implementation of the model: systematic approach (a set of interrelated components - the objective and the subjects of the pedagogical process, educational content, methods and forms), cultural approach (culture as the means of creative self-expression), activity-oriented approach (organization and management of the child activities), and the principles of multiculturalism (a characteristic feature of the educational environment), polysubjectal principles (the integration of the various institutions - school, family and society - in the solution of educational problems).

For the organization of effective work on the young schoolchildren creative development within multicultural environment, the following pedagogical conditions are identified:

1. Organization of pedagogical interaction as freedom of creativity;

2. Organization of creative space-the educationally convenient developing environment.

3. Educational support of the family (involvement of parents in active forms of joint creative activity with younger students; pedagogical education of parents).

The implementation of the selected educational conditions within the educational process is modeled in the experimental educational program "Steps of children's creativity". In selecting the content and determining the stages of introducing children to national traditions, we relied on the approaches to the steps of acquaintance with the peoples living in the region and the principles of interlocutory cultures distinguished by M. M. Bakhtin: from the culture of the native people to the culture of the peoples of cohabitation. At the core of the Volga region 
culture lies the convergence of its constituent authentic peoples' cultures, among which, in the process of content selection, Russian, Tatar, Chuvash and Mordovian national traditions are singled out.

To form an objective view of the working state in the educational practice of primary school and identify the initial level of the creative development of children, organically interrelated and interdependent criteria and indicators were determined (Table I).

TABLE I. CRITERIA AND INDICATORS OF YOUNG SCHOOLCHILDREN CREATIVE DEVELOPMENT WITHIN MULTICULTURAL ENVIRONMENT BY MEANS OF FOLK TRADITIONS

\begin{tabular}{|l|l|}
\hline \multicolumn{1}{|c|}{ Criteria } & \multicolumn{1}{c|}{ Indicators } \\
\hline $\begin{array}{l}\text { Completeness of the } \\
\text { knowledge about the tradi- } \\
\text { tions of the Volga region } \\
\text { peoples (cognitive compo- } \\
\text { nent) }\end{array}$ & $\begin{array}{l}\text { Availability of the Russian, Tatar, Chuvash } \\
\text { and Mordovian people folk traditions } \\
\text { knowledge: on national holidays; on folklore, } \\
\text { its genres, musical instruments, national cos- } \\
\text { tumes, embroidery, ornaments etc. }\end{array}$ \\
\hline $\begin{array}{l}\text { Development of an emo- } \\
\text { tional attitude to folk tradi- } \\
\text { tions; positive motivation } \\
\text { for creative activity (emo- } \\
\text { tional and motivational } \\
\text { component) }\end{array}$ & $\begin{array}{l}\text { Showing interest in folk traditions. The pres- } \\
\text { ence of a positive attitude to creative activity }\end{array}$ \\
\hline $\begin{array}{l}\text { Development of skills in } \\
\text { creative activity (creative } \\
\text { and activity-oriented com- } \\
\text { ponent) }\end{array}$ & $\begin{array}{l}\text { Distinguishing and recreating national cus- } \\
\text { toms and traditions in the process of creative } \\
\text { activity, inclusion in national holidays }\end{array}$ \\
\hline
\end{tabular}

Diagnostic examination allowed to make an objective view of the work state on the problem of research in the practice of education and training and led to the following conclusions: children do not possess sufficient knowledge of folk traditions, do not express positive emotions and interest in creative activity; the initial level of the children creative development can be described as low and medium. The ascertaining stage of the experiment made it possible to determine some dependencies between the content of the educational process and creative development. The desire to participate in creative activity is directly proportional to the expression of interest towards the way of presenting the information by the teacher: the higher the level of interest towards the material is, the more stable is the desire for creativity in the child. The degree of the child's creative expression depends on the organization of the educational process, including independent creative activity of younger students.

\section{RESUlTS}

For the purpose of carrying out experimental work, control and experimental groups were formed. Requirements for the definition of experimental and control groups: identity of the ethnic structure, level of creative development, material base and methodological support. The ethnic structure of the participants, who were involved in the experimental work, was analyzed at the ascertaining stage. We have obtained the following results: 55\% Russian, 24\% Tatar, $15 \%$ Chuvash, $6 \%$ Mordovian. Based on the principles of consistency of introducing children to folk cultures and the results of the experimental groups ethnic structure, the material on folk traditions of the Russian, Tatar, Chuvash and Mordovian peoples was included to the content of the program.
126 primary school children were evaluated in order to identify the initial level of the children creative development. In the evaluating process the following means were used: pedagogical observation during educational and independent activities, holidays and entertainment; the analysis of children creative works; individual interviews; the method of expert evaluations when performing individual tasks was used. As a result of the observation in the process of educational activities, it was discovered that students lack basic knowledge about folk traditions and skills in creative activity. Observations during holidays and entertainment, competitions and quizzes showed that $89 \%$ of children's knowledge and ideas about the traditions of the Volga region are very superficial, poor in content. $61 \%$ of children do not show a keen interest in folk traditions. Having studied the creative products of children's activities (drawings, molding, applique works, crafts, etc.), we discovered that students are not familiar with folk holidays, national clothes, household items, folk songs, games and musical instruments of the Volga region.

Educational work was carried out on the basis of specially created educational conditions and was framed in three directions. The first direction is related to the cognitive component: children were introduced to folk holidays, everyday life, traditions, arts and crafts, and the history of national clothing, folk instruments and genre diversity of musical works. The second one is related to the emotional and motivational component: organization of folk culture mini museums and meetings with folklore groups. Various forms of work (themed, complex, integrated, game classes, competitions, quizzes) contributed to the exhibiting of children's bright, sincere emotional activity. The third direction is connected with the creative activityoriented component. It included the use of acquired skills by children during independent creative activity.

\section{DISCUSSION}

The efficiency of the research was achieved through special selection and inclusion in the educational process of national customs and traditions of the Volga region, the content of which was intelligible to the emotional experience of students and their ability to empathize. Pedagogical interaction as freedom of creativity was carried out in the fact that each student could freely choose the direction of his creative work according to his interest. The development of interest towards folk traditions always started with the acquiring initial knowledge and organization of practical creative activity. Problematic situations were created to facilitate this process. The organization of the developing environment creative space was carried out within the activities of the "Native land" club. The staging of folk tales, performance of carols, ritual songs with instrumental music and acting out the fragments of folk rituals contributed to the developing of the ability to recreate people's customs and traditions in creative activity and brought respect for them. Visiting the Museum of architecture and local lore, watching cartoons based on folk tales and legends, drawing up a family genealogical tree, participating in folk festivals enriched the children's knowledge about the traditions of the Volga region peoples. Educational support of the family was carried out in the form of conversations, consultations, thematic exhibitions, competitions, joint events, music halls, workshops, questionnaires. The attention of parents was 
focused on the museum work and the use of family national traditions in the process of educating children. Parents and children took an active part in collecting items of national culture, familiarization with which was important for the study of the peoples' traditions reflected in songs, games, rituals, and holidays. The celebrations of Maslenitsa, Sabantuy, Akatuy, Savarni, Uyav were organized annually.

The results of observing the activities and behavior of children in extracurricular activities showed that the invested effort contributed not only to the accumulation of knowledge about folk traditions, but also formed a positive attitude of younger students to them. The children's interest in activities related to folk art had increased. The method of observation helped to establish the degree of awareness and sustainability of interest towards folk culture. In educational activities involving music, art and technology, the participants began to ask questions on topics related to the life and everyday routine of different peoples. The study of children's creative works (drawings, appliqué works, molding, miniatures, scrapbooking, and posters) allowed us to note their desire to use the elements of national patterns. Many of the children's works are distinguished by original and imaginative structure. It shows the ability of children to apply their knowledge to different activities. Pedagogical observation during holidays, competitions, quizzes, games showed that children learned much for their age about the culture of the Volga region peoples. They developed ways of creative expression, which was the reason for the bright emotional experience, the desire for creative activity and the desire to share their knowledge.

Therefore, the children had a noticeable change in the level of their creative development: a significant increase in highlevel indicators was recorded: on cognitive, emotional and motivational, and creative activity-related components.

Practical significance of the research results: the model of creative development of primary school children in a multicultural educational environment through folk traditions was tested; the "Steps of children's creativity" program was introduced into practice of primary school education. Theoretical positions and conclusions can be used in the training of primary general education teachers, as well as in the practice of educational organizations.

\section{CONCLUSION}

Taking into account the results obtained at different stages of the study, the following conclusions are made. The effectiveness of younger students creative development process was ensured by creating the necessary educational conditions. The developed content, methods and techniques, situations in which they can be used, creative tasks in combination with educational conditions built on the principles of continuity in learning, provided efficiency and proved the possibility of younger students creative development problems solving in a multicultural educational environment. The distinguished criteria of primary schoolchildren creative development components (cognitive, emotional and motivational, and creative activity-oriented components) and the corresponding qualitative indicators allowed determining the levels of their development (low, medium and high). Positive dynamics was recorded within the experimental groups of children. It provides grounds for a general positive conclusion about the effectiveness of the work.

Only some problems of young schoolchildren creative development within multicultural environment based on folk traditions are solved in our research. The age aspects of the problem still remain beyond the scope of the subject: on the earlier and later age stages. The problem of acquiring and systematization of the knowledge about the traditions of the Volga region peoples, as well as their impact on the creative development of younger students can still be studied at a deeper level.

\section{References}

[1] Bakhtin M.M. Collection of works in 7 volumes. Volume 1. Philosophical aesthetics of the 1920s. Kaluga: GUP Oblinzdat. 2003, 961.

[2] Berdiaev N.A. Philosophy of Creativity, Culture and Art: In 2 vol. M: Art. 1994.

[3] Bogoyavlenskaya D.V. Who or what is the subject of creativity. Proceedings of the International Scientific and Practical Conference "Humanitarian Reasons for the Social Progress of Progress. Russia and Modernity". M., Ministry of Education and Science of the Russian Federation FSBOU VPO, Moscow State University of Design and Technology, Moscow, April 25-27. 2016, pp. 41-46.

[4] Vengotsky L.C. Imagination and Creativity in Childhood. Spb.: Union. $1997,96$.

[5] Druzhinin V.N. Psychology of General Abilities. St. Petersburg. 2008, 358.

[6] Dybina O.V. Integration of educational spheres in the pedagogical process of DOE Mosaika- Synthesis. 2012, 80.

[7] Zabbarova M.G., Greeneva E.A. Theoretical and methodological foundations of the multiethnic culture of younger teenagers: monograph. M: Prometheus Publishing House. 2016, 141.

[8] Zavgorodny A. L. Creativity of the "free spirit" in the concept of Nikolai Berdiaev. News of the Russian State Pedagogical University named after A.I. Hercen. 2009, 93, pp. 158-161.

[9] Ilyenkov E.V. Philosophy and Culture. M.: Politicizdat. 1991, 464

[10] Kutbiddinova R.A. Multiethnic educational environment of higher education institutions as an object of psycho-pedagogical research. Journal of Tomsk State University. 2009, 326, pp. 174-179.

[11] Leontiev A.N. Activity. Consciousness. Personality. M.: Meaning, Academy. 2005, 352.

[12] Luke, A.N. Thinking and Creativity. M.: Politizdat. 1976, 144.

[13] Lurie L.I. Modeling of regional educational systems: Study. M.: Gardariki. 2006, 287.

[14] Maslou A. Self-actualizing personality. M. 1985, 117.

[15] Lysyakova I.P. Methods of teaching Russian as a non-native language: a training manual. Moscow: Rusines University. 2015, 160.

[16] Nagatkina A.V. Philosophy of N.A. Berdyaev creativity. A young scientist. 2018, 24, pp. 366-368. URL https://moluch.ru/archive/210/51454/.

[17] Olport G. Personality Formation: Selected Works. M.: Meaning. 2002, 462.

[18] Multiethnic Education: Practice of Educational Institutions: Collection of Scientific and Methodological Materials. Stavropol: Department of Education of the Stavropol Administration, Data World LLC. 2008, 156.

[19] Kirnarskaya D.N. Psychology of musical activity: Theory and practice: Study manual for of pedagogical institutions musical faculty students. M.: Publishing Center "Academy". 2003.

[20] Rubinstein, Basics of General Psychology. SPb, Peter. 2002, 720.

[21] Alexsandr S. Kuznetsov. Russian Professor's meeting. Russian Journal of Physical Education and Sport. 2019, 14(1), pp. 17-22. DOI: 10.14526/2070-4798-2019-14-1-18-24

[22] Khodov B.M. Psychology and psychophysiology of individual differences: selected psychological works. 2nd ed. M.: MPSI; Voronezh: NPO MODEK. 2009, 638. 